\title{
Inclusive Management Through Gender Consideration in Small-Scale Fisheries: The Why and the How
}

\author{
Maricela de la Torre-Castro* \\ Department of Physical Geography, Stockholm University, Stockholm, Sweden
}

\section{OPEN ACCESS}

Edited by:

Robert Pomeroy,

University of Connecticut,

United States

Reviewed by:

Brett W. Molony,

Oceans and Atmosphere,

Commonwealth Scientific and Industrial Research Organisation

(CSIRO), Australia

M. Cristina Mangano,

Bangor University, United Kingdom

${ }^{*}$ Correspondence: Maricela de la Torre-Castro

maricela@natgeo.su.se

Specialty section:

This article was submitted to Marine Fisheries, Aquaculture and Living Resources, a section of the journal Frontiers in Marine Science

Received: 15 December 2018 Accepted: 11 March 2019

Published: 29 March 2019

Citation:

de la Torre-Castro M (2019) Inclusive Management Through Gender Consideration in Small-Scale Fisheries: The Why and the How.

Front. Mar. Sci. 6:156.

doi: 10.3389/fmars.2019.00156
In a world in which ocean degradation is widespread and aggravated by the effects of climate change, there is a need to contribute with new management approaches to ameliorate the situation. Here, inclusive management is proposed as such an alternative. This contribution argues that including all genders in the management process is needed and the inclusion itself can generate new ways to solve problems. An assessment of findings from literature of the positive aspects when considering gender in environmental governance is presented and related to the specific situation of small-scale fisheries (SSF). These positive findings are explained in terms of (1) Participation, (2) Space, actors and activities, (3) Economic power, and (4) Equity and environmental stewardship. Further, a practical approach is taken and a model for gender inclusion in coastal/ocean management for SSF is presented and illustrated with a case of seagrass SSF in East Africa. The central argument is that in view of ongoing coastal/ocean degradation and the moderate governance and management success, it is worth trying management approaches that consciously and explicitly consider gender and diversity of actors. This will bring central actors (e.g., women not previously considered) into the management process and will provide the base for better governance and policy reform.

Keywords: gender, gender and environment, small-scale fisheries, coastal management, ocean governance, marine spatial planning, seagrass conservation, Zanzibar

\section{INTRODUCTION}

In the current situation of ocean/coastal degradation as well as the uncertainty of human fate due to climate change (IPCC, 2018) it is urgent to provide new angles and solutions to ocean/coastal problems. In this contribution, the benefits of adopting an inclusive ocean/coastal management approach, which incorporates gender aspects for small-scale fisheries (SSF), are presented. Inclusive management is defined here as any management initiative that strives toward sustainability while consciously and explicitly considering the diversity of actors who have a stake in the social-ecological system. Inclusive management considers men, women, children, elders and minorities. This approach is a new proposition and, as such, is not yet tested although it shares commonalities with established participatory approaches and co-management as well as with inclusive development (Koralagama et al., 2017). The main particularity of this approach is that it brings to the table "gender analysis" for governance and management enhancement (de la Torre-Castro et al., 2017). The key argument is that given previous experiences, it seems fruitful to have a gender perspective in SSF governance, management and conservation. This contribution develops the argument using knowledge from the vast field of gender and environment and through the author's own experience working with gender and SSF associated with seagrasses in East Africa. This research does not cover each idea presented on gender and environment nor all schools of thought and ways to approach 
it. Instead, the focus of the contribution is on exposing the various positive arguments for gender inclusion, which provide evidence for ways in which governance, and management approaches can be improved, and policy reformed.

The contribution draws attention to the importance of increasing the diversity of actors and voices involved in order to improve SSF governance and management. The article is organized as follows; first, key aspects related to gender are introduced, then arguments from the literature which support gender and diversity are presented, this is followed by the presentation of a hands-on generic model to accommodate and study gender in ocean/coastal areas with SSF and a specific application of the model to the case of SSF associated with seagrasses in Zanzibar, Tanzania. The article ends with conclusions and thoughts for the future.

\section{KEY GENDER ASPECTS}

At a basic biological level, human beings are sexual organisms (male or female). Exemptions, however, do exist and in some countries, law recognizes a "third sex" (for example in South Africa and Australia); other countries have an even more complex view of the issue. Here, the focus is on men and women, but the same arguments can be extended to minorities if wanted/needed.

For humans, which are in essence complex creatures, sex is not enough to understand behavior; and behavior is a key variable for understanding natural resource use and management. As such, considering gender has deep policy implications. Gender is useful as it refers to the cultural, normative and social attributes of being a man or a woman. There are different definitions of gender, but all of them incorporate the social construction of being a man or a woman and the power differences associated to them. The history of the concept can be traced all the way back to Plato and later on to John Stuart Mill, and in the 1970s and 1980s to Catharine MacKinnon and Andrea Dworkin (Nussbaum, 1999). Gender takes into consideration the contextual factors framing actions, attitudes, aspirations, capabilities, etc. of a man or a woman (Harding's, 1986; Gregson et al., 1997). It also considers what is expected from different sexes from a societal perspective. In addition, gender considers the interrelationships between and within categories; who has power to do what, how and why, who benefits and who do not. As such, gender analysis is a powerful tool to understand society and identify areas that need improvement (Davis and Nadel-Klein, 1992; Jackson, 1994; Bennett, 2005; Sprague, 2005).

During the last decades, gender has gained importance due to the historical inequalities between men and women (e.g., Bryson, 2003; Lykke, 2009). There is an honest effort to try to reverse such inequalities, and although concrete results have been moderate and not as tangible as desired, advances have been achieved and practically all important high level global institutions consider gender as central to their own organization and areas of work (e.g., UN, EU, UNDP, WB, etc.).

In relation to SSF, the FAO voluntary guidelines for SSF (FAO, 2015) includes a section on gender equality. The text makes clear that discrimination against women in SSF should be challenged and that gender mainstreaming should be an integral part of SSF policy. A whole handbook for implementation was created 2 years later (FAO, 2017). These recent events will certainly bear fruit in the coming years, especially as the number of scholars working with gender and SSF seems to be growing (see for example Vol. 17, in Maritime Studies Journal 2018).

\section{ASSESSING THE LITERATURE FOR POSITIVE FEATURES OF GENDER INCLUSION: THE WHY}

This section presents the positive aspects found (in the literature and in author's experience) when including a gender perspective in environmental policy, governance and management ${ }^{1}$. The section is organized into the following categories; (1) Participation, (2) Space, actors, and activities, (3) Economic power, and (4) Equity and environmental stewardship.

\section{Participation}

Participation is one of the major reasons to include women in management efforts. How fair, effective and realistic can management be when excluding half of the population? Different projects show that including gender in management and allowing women to participate in decision-making, monitoring, implementation and evaluation is positive (e.g., Westermann et al., 2005; Agarwal, 2010; Barclay et al., 2017). One of the main arguments put forward in the literature is that women have different types of knowledge, observations, experiences and interpretations that may enrich management and provide new perspectives when analyzing problems and when tailoring solutions (e.g., World Bank [WB], 2010, 2015; Klugman et al., 2014). Women's participation also leads to a different kind of leadership that can facilitate the navigation of difficult policy issues (UNEP, 2015). Women's participation, and gender analysis more generally, are matters of justice and equity (Di Chiro, 2008) and may lead to the recognition of different arenas in which different actors (co-) work and (co-) produce, as well as the different contributions by different actors, for example in terms of conservation efforts, marketing, direct extraction, etc. Participation has also been a way to foster emancipation and empowerment and in some cases has led to building coalitions between different and previously disaggregated groups (e.g., Kleiber et al., 2015). It has created a novel and open space for networking (Arora-Jonsson, 2014) and not seldom has expanded the focus of the problems from environmental management to broader societal issues (e.g., Onyango and Jentoft, 2011; AroraJonsson, 2014). Participation is considered a key point for future sustainability agendas (Agenda 2030, 2015).

\section{Space, Actors and Activities}

Obviously, in order to manage a system, knowledge about the system is a prerequisite (Kooiman et al., 2005; Schultz et al., 2007).

\footnotetext{
${ }^{1}$ For a view, also discussing negative gender experiences and challenges see AroraJonsson (2014).
} 
From a social-ecological perspective, social and ecological parts of a system are equally important and thus, relevant information about both is needed. First, a social-ecological mapping or inventory is needed (Schultz et al., 2007). It is important to have information about the characteristics of the ecosystems in question, together with the resource users and their relation to management plans. In addition, it is critical to know/understand images, norms and attitudes in the local context (Song et al., 2013). Women have been largely excluded as users and stewards of natural resources, at least in contemporary approaches to resource management taking place in different governmental agencies. It is possible to find examples of matriarchies and traditional or local ecological management systems, but these have not been dominating lately.

In coastal management, Diamond et al. (2003) advocates for a gender perspective. Adding a "gender lens" in SSF will provide a clearer picture of the whole system (Williams, 2008). It is critical to know who is doing what in the coastal zones (in specific ecosystems and within larger seascapes). This includes information about the roles of the people using the different coastal spaces, the resources used and the relations of power over places and resources. People work in the various ecosystems of the coastal zones. This work can be defined as "the active labor-based interaction of human beings and the material world" (Menon, 1991). Women and men perform different activities. Men normally "fish" as their main occupation (sometimes combined with other activities) while women normally have many roles such as invertebrate collector, fisherwoman, trader, processor, etc. (Weeratunge et al., 2010). Without doubt, mapping the actors, resources and activities will increase the general knowledge of the coastal zone and help in the identification of critical management and policy gaps. It will provide a visualization and understanding of the work and movement of people. For example, in Mayotte, aerial pictures taken at different times and seasons were used to investigate the activities and uses in the intertidal areas. The gendered differentiated practices can be analyzed in such a way too. Recent mapping of seascapes has been an important tool to identify key ecosystems and areas of conservation (Palafox-Juárez and Liceaga, 2017). One issue that becomes clear when working with gender and coastal resources is the lack of existing genderdisaggregated data (Williams, 2002; Bennett, 2005; FAO, 2012; Fröcklin et al., 2013; Kleiber et al., 2015). In some parts of the world, attention to gender aspects is higher and has been very positive particularly in community-based management; see for example, initiatives taking place in the Pacific, South East Asia and East Africa (2,3 and Fröcklin et al., 2018, respectively).

Having clear information about defined spaces, actors, activities and their overlap may facilitate the acquisition of such data. Spatial analysis also has the potential to reveal issues of environmental justice; who has access to the most valuable resources and ecosystems? Why are specific patterns found? Who decides what? In what way? How do the decisions and interrelations at the household level affect the use of coastal spaces and resources and vice versa?

${ }^{2}$ https://www.spc.int/resource-centre

${ }^{3}$ www.genderaquafish.org
Studies considering natural and social domains have received much attention in gender and environment (e.g., Rocheleau et al., 1996) but actual mapping and linking between the ecological and the social dimensions have not been prominent in the literature. It can be argued that in gender and environmental studies there is bias toward consideration of the social side rather than the ecological side. There is also a bias about studied systems; gender and environment research has tended to focus on forests, fresh water provision and disaster management and far less on ocean/coastal systems and their associated fisheries (SSF or others). Studies that have considered space, actors and activities have found that gender is a key factor that cannot be ignored in management and policy (Thyresson et al., 2013; de la TorreCastro et al., 2017; Drury O'Neill and Crona, 2017; Picaulima et al., 2017; Drury O’Neill et al., 2018).

\section{Economic Power}

At the core of gender studies, analyses of economic inequalities are found. Historically, men have been seen as breadwinners and women as caretakers of the household and children. A key focus in feminism is to achieve women's economic independence and, as a consequence, the power of decision-making. Boserup's work (Boserup, 1970) constitutes a keystone study. Boserup analyzed the economic contributions of women and linked them to development. Since then, a common result of research in this area has been the clear existence of economic asymmetries between men and women dealing with natural resources (e.g., World Bank [WB], 2012, 2015). These economic concerns have been reflected in paradigms of thought from women in development (WID) to women and development (WAD) and later to gender and development (GAD); it is beyond the objective of this article to review all of them (see for example Rathgeber, 1990), but suffice to say that economic inequality has been given a lot of attention. Issues of economic inequality are important in both developed and developing nations. Naturally, the World Bank addresses this agenda (World Bank [WB], 2006, 2010, 2012). In general, economic equality and gender integration in labor and markets is highly beneficial (Cotter et al., 1997). In addition, women's missing potential in development can be considered a deep loss (Duflo, 2012). Economic development normally decreases inequality and benefits the whole society but specially women. So, still policy interventions are needed to assure gender equality (Duflo, 2012).

Recent research in SSF found that economic asymmetries are a common feature in both finfish and shellfish associated SSF and constitute huge management challenges (Barclay et al., 2018; Drury O'Neill et al., 2018). Fröcklin et al. (2013) analyzed the market activities of fish traders and concluded that economic gender inequalities were present in the system, but additionally that, gender insensitive policies masked the feedback needed for learning and adaptive management by missing key actors, in this case women fish traders and their activities. A recent study also shows that, globally, women are commonly economically active in the coastal zones, but their contributions are neither registered in official records nor recognized by society (Kleiber et al., 2015). In SSF it is thus necessary to analyze what the critical assets are, not only in terms of direct ecological goods (such as fish and 
shellfish) but also in terms of conservation or potential ecosystem services that may provide higher revenues (for example as carbon sinks or as sites for ecotourism). Linked to the point above on mapping, who has the access to assets and resources with higher economic value and how the distribution of wealth looks like? Who has the access to markets and information? How can economic development be created in an equal and just way? Therefore, integrating economic aspects and gender in analysis of SSF will highlight the aspects explained above. There is also a need to go beyond the gender/ecosystem link and analyze the whole living situation, especially in tropical rural communities, paying attention to both productive and reproductive work, and from the individual level to whole household dynamics. The potential of gender inclusion for progress toward a green economy and overall sustainable development has also been identified (Agarwal, 2012).

\section{Environmental Stewardship and Equity}

Ecofeminism has argued that there is a natural connection between women and environment (e.g., King, 1983; Shiva, 1989). This school of thought argues there is a naturalistic caring inclination; since women are "birth givers" and have an intimate connection with children it is argued that this is extended to nature. Because of pregnancy and childcare, women also are less likely to move; and therefore considered as the primary actors in environmental care with high levels of local ecological knowledge. Ecofeminism has been criticized and marginalized for its essentialism and lack of stringent analysis (e.g., Jackson, 1993; Jackson, 1994; Leach, 2007). However, Thompson (2006), revising the early work of Merchant (1980) argues for a reevaluation of ecofeminism. Thompson's argument is that ecofeminism's central thesis is still valid; since it explains the commonalities of human (women) and nature domination that stem from positivistic science and capitalism. The objective of this section is not to defend ecofeminism, but to problematize and link to empirical studies showing that in many cases women do care for the environment. Women have been shown to: be more supportive to wildlife (Arjunan et al., 2006); improve forest management (Agarwal, 2009a,b); promote positive collective action and social norms for better management (Westermann et al., 2005); include more ethical aspects for holistic management (Lauber et al., 2001); and to be more cooperative in different settings with environmental importance (Revollo-Fernandez et al., 2016). Elderly women have also been found to be crucial to retaining and passing down traditional ecological knowledge (Singh et al., 2013). It has also been found that women university students have smaller ecological footprints than male counterparts (Medina and Toledo-Bruno, 2016), women engage in more pro-environmental behaviors (Hunter et al., 2004) and in countries with higher proportion of women in their parliament, the likelihood of ratification international environmental treaties increases (Norgaard and York, 2005). Ecofeminism and Political Ecology have emphasized the role of women as leaders in conservation. This type of strong leadership with local resistance has also been found in coastal systems; in Peru, for example, women were leaders to defend shrimp farming developments through grassroots mobilizations (Veuthey and Gerber, 2012).
However, the reasons for caring about the environment may vary, and in many cases fulfill material and work needs (Jackson, 1993; Dankelman, 2001). Additionally, there is little information about the actual impacts of those actions on the environment (positive or negative). Evidence presented by Agarwal from forests in India and Nepal is positively convincing (Agarwal, 2010), but other studies have not found clear links between women and better environmental conditions or conservation (e.g., Nugent and Shandra, 2009). A review of ecological restoration and gender found positive evidence that integrating gender in restoration efforts giving higher efficiency and effectiveness, but as gender is generally not taken into consideration in restoration, it is difficult to draw overall conclusions (Broeckhoven and Cliquet, 2015). In development, women are often considered as agents of change and drivers of sustainable development (e.g., Braidotti et al., 1994; UNEP, 2015). But there is a warning here; women are already facing the so called "double burden" of work and household duties (or the "triple burden" of productive, reproductive and community work according to Moser, 1989). Should they take one more task of being better environmental stewards? Dankelman (2001) answers with a clear no; "care for the environment should not be added to the long list of tasks for which women are already responsible." Here, gender analysis is useful to place the burden (and joy) of environmental care in more equitable terms. It may also open up the possibility of addressing inequitable food security and childcare provision. Women have had enormous responsibility related to food security and meeting wider societal needs (Boserup, 1970), especially in fisheries where they play a key role in poverty alleviation and provision of high quality protein (Harper et al., 2013; Béné et al., 2016). Gender analysis may help to identify areas in which men can contribute more. Needless to say, this implies a reconsideration of management, conservation and policy, in which both men and women and their interrelations are important, as well as how those interrelations relate to the environment. This new way of linking gender, management, conservation and policy necessarily deals with equity and justice, and clearly links to the first point of participation.

\section{ACTIONABLE RECOMMENDATIONS. A SOCIAL-ECOLOGICAL MODEL FOR GENDER INCLUSION IN OCEAN/COASTAL SSF MANAGEMENT: THE HOW}

While the previous section uncovers the positive aspects of using gender in environmental management and governance, it says little about the practical way to do it and about the difficulties of working with gender. Some of the difficulties when working with gender are explained briefly below.

Gender is not completely unproblematic (Hawkins et al., 2011; Arora-Jonsson, 2014); there are methodological, ideological and philosophical challenges when working with gender. At the core, the main difficulty is defining what gender really 
is (Arora-Jonsson, 2014), considering the context and posing adequate relevant questions (Scott, 2012). Gender has to be understood in its historical context. While the concept was created to avoid biological determinism, recent work problematizes the indivisibility of the biological and the sociocultural. There is a need for new categorizations that allow us to deal with duality without falling into old simplifications (for a discussion see for example Lykke, 2009). Another difficulty when working with gender is that gender is not a static category, rather a process changing over time and space. This conceptualization becomes useful to analyze history and transformation and to dive deeper into interrelations between gender, the physical environment and socio-cultural processes (Nightingale, 2006). In addition, gender research has been shifting the focus of the analysis. It has been argued that gender analysis has moved the focus from men to women and then to men again. However, Kabeer (1994) refutes this dilemma, stating that gender analysis is not in opposition to highlighting the oppressed gender (normally women) and inequalities. She makes a parallel with class analysis in which the situation of the poor and disadvantage is naturally emphasized and argues that, therefore, there is no real tension between gender analysis and a fight for women's rights and emancipation.

In coastal/marine environments, studies of gender are scarce, so the initial focus needs to be around mapping and characterization of the social-ecological setting. As basic knowledge is acquired, steps toward more complex socialecological analysis can be taken. Here, a practical approach is adopted by providing a generic model to integrate the different aspects of the management process into a comprehensive unit including gender. How to go on? How a can a researcher or a management agency work with these factors in a hands-on way? The intention of the model is to facilitate the process and to consider the whole setting, incorporating biophysical, ecological, social and economic elements. The model is built upon layers of knowledge that are superimposed on each other (similar to a GIS model). It departs from the biophysical reality and builds on complexity with higher levels of social understanding and interrelations between humans-nature and humans-humans. To acquire knowledge about the different layers, different epistemologies can be used. The challenge for the researchers and/or managers is to link and understand the rich information in a holistic way. Table 1 presents the different layers and key aspects of the model. Parts of the model has been applied for the case of SSF associated with seagrasses in Zanzibar, Tanzania. A brief presentation of the case and the novel information that the inclusion of gender provided for management enhancement is given after the table.

\section{GENDER IN SMALL-SCALE FISHERIES ASSOCIATED WITH SEAGRASSES}

The model (Table 1) has been partially applied to the case of SSF associated with seagrasses in Zanzibar, Tanzania. The knowledge generated corresponding to the different model layers can be found in specific publications (Fröcklin et al., 2012/Seaweed farming and farmers' health,
2013/Fish traders, 2014/Invertebrate collection, 2018/Small-scale innovations; Nordlund et al., 2014/Invertebrate collection; de la Torre-Castro, 2012/Governance; de la Torre-Castro et al., $2017 /$ Gender analysis and seascape). Here, only the main findings and benefits of including gender in SSF research are highlighted and illustrated.

Seagrasses are an important fishing ground all over the world (Nordlund et al., 2018) in which SSF are highly represented. Particularly in Zanzibar, Tanzania, they provide a large amount of ecosystem goods and services, such as seagrass associated fish and invertebrates, bait for fishing, fishing grounds and substrate for seaweed farming. Other services were the use of seagrass as fertilizers, for traditional medicine and in cultural activities (de la Torre-Castro and Rönnbäck, 2004). Since seagrasses are part of larger biophysical units (i.e., seascapes) providing an even larger amount of services, the characterization of the seascape was a major part of the gendered social-ecological analysis and was done through transects, satellite pictures, aerial pictures and observation in selected places in Zanzibar (de la Torre-Castro et al., 2017). Mapping of the people allowed the collection of disaggregated data on men and women and using interviews and diaries enabled the performance of a thorough gender analysis. The key factors for understanding the gendered social-ecological situation were: (1) To have a spatial view of resources and resource users along the seascape, (2) To identify the key goods and services that differ between men and women, (3) To identify key ecosystems for subsistence and income provision, and (4) To identify management gaps and/or biases (see Table 1). The seascape characterization provided the first layer of knowledge (the biophysical space and its condition with related natural resources). The mapping of the people and the management options were then superimposed on this (layers 2, 3, and 4). The result provided a robust understanding of the situation. The most important management result was that men-dominated activities - in this case, coral-associated SSF - are the ones given attention and are backed up economically by governmental agencies (Figure 1). In addition, gendered inequalities were found in income. In almost all cases, men earned more than women for all coastal/marine related activities. Another key finding was that the importance and perception of ecological goods and services was also gendered (recently the gendered nature of ecosystem services has been highlighted e.g., de la Torre-Castro et al., 2017; Fortnam et al., 2019; Nagoli et al., 2019). Women participation in management and decision-making was low and inequalities were found not only in economic terms but also in terms of household chores distribution, traded fish, access to markets, etc.

Specifically in relation to management of seagrass meadows, it was found that management plans tend to focus on men and finfish fishing in corals, whilst in fact, many of the activities with the greatest impact on seagrass meadows were womenrelated in form of invertebrate collection (Nordlund et al., 2010; Fröcklin et al., 2014), growing of red seaweed over the meadows (Fröcklin et al., 2012) and subsistence fisheries (Williams, 2002; Matsue et al., 2014; de la Torre-Castro et al., 2017). Fröcklin et al. (2014) showed that collection activities could cause negative changes in invertebrate populations in a relatively short time span (e.g., 5 years). Seaweed farming 
TABLE 1 | A generic social-ecological model for inclusive management through gender integration in ocean/coastal settings with associated small-scale fisheries (SSF).

\begin{tabular}{|c|c|c|c|}
\hline $\begin{array}{l}\text { Layer of } \\
\text { knowledge }\end{array}$ & Possible methods to acquire information & Key issues and comments & $\begin{array}{l}\text { Strengthen "positive" } \\
\text { gender aspect (see } \\
\text { Assessing the Literature for } \\
\text { Positive Features of Gender } \\
\text { Inclusion: The Why) }\end{array}$ \\
\hline
\end{tabular}

\section{Mapping and} characterization of the seascape

\section{Mapping and} characterization of resource users

\section{Gender analysis}

4. Integration of information

\section{Tailoring} management plans

\section{Implementation}

7. (Re-)

Evaluation and iteration
Transects, aerial pictures, satellite photographs, etc. Ecological studies of ecosystems and associated species

Social-ecological inventories

Focus is on gaining knowledge about the biophysical component

Photographs, ethnographic research (e.g., following people in their daily activities), interviews, focus groups, participatory mapping, analysis of data loggers (e.g., fisher boats and fishing grounds, counting men and women on board and their roles), activity diaries Focus is on knowledge about disaggregated resource users, activities and ecosystem goods and services of relevance

Different types of interviews, observation, different constellations of focus groups, historical analysis, analysis of socio-cultural context, ethnographical analysis, sociology, political science methods, political ecology, different feminist school of thought, Women and Development approaches, Livelihoods approach There are no simple recipes to analyze gender. Each case is unique.

Focus is on disentangling who has power to do what and why, and posing relevant questions.

Examples of key questions:

What is the explanation for the resource and ecosystem use observed?

What are the gendered relationships vis-à-vis nature? What are the interrelations between women and men? How do activities in the coastal zone relate to the household?

What are the societal restrictions for each gender? What are the societal expectations for each gender in this particular context? What are the institutions in place reinforcing inequality? Interdisciplinary analysis, complexity analysis, use of GIS (Geographical Information Systems), including participatory GIS; participatory methods (to understand the current situation), participatory scenario building (to understand possible futures and areas for transformation); analysis of norms, images, views and mental models

Focus on linking the previous layers of information Integration of information into existing management structures (e.g., Integrated Coastal Zone Management, Marine Spatial Planning, Ecosystem based management, MPAs, etc.), a total change in management approach may also be needed, but that transformation is more costly to carry out (in both time and resources)

\section{Participation, co-management, adaptive}

co-management, community based-management; etc.

Performance analysis, participatory methods, gradual model adjustment
Knowledge about the basin and key ecosystems and species is needed

Space

Knowledge about who is doing what along the seascape is needed, identification of key activities, ecosystems and resources used

Identification of key gendered goods and services

Harding's (1986) typology can be used as a heuristic tool for this analysis. This typology comprises three categories:

Gender structure which relates to the working activities resulting in a division of labor (see section about mapping above).

Gender symbolism, which encompasses the socio-cultural factors defining what, is perceived as feminine or masculine.

Individual gender which concerns how identity is constructed and how it may change over time. This approach has been very useful as the three categories are clear and the analysis provides a strong basis with which to gather initial knowledge about the gendered situation in coastal areas. After having this knowledge base, further steps may include other types of more complex analysis, for instance using intersectionality.

Diversity of knowledge and actors is needed for the integration

Measures to reduce the identified inequalities in participation, access to resources, access to economic benefits, conservation and planning

Identify key actors and positions to implement the measures, set clear objectives, indicators of success and time targets

Analyze the performance, continue if positive, adapt and change if negative.

Evaluate in a holistic manner both biophysical indicators and social indicators with special focus on gender and equity.

Managers should always provide feedback to the actors
Space, actors and activities

\section{All combined}

This is the main contribution of "inclusive management" and "social-ecological" gender analysis

Economic analysis should be included here to analyze inequalities
Participation Equity

Participation

Equity

Participation

Environmental stewardship and equity

Participation

Equity 


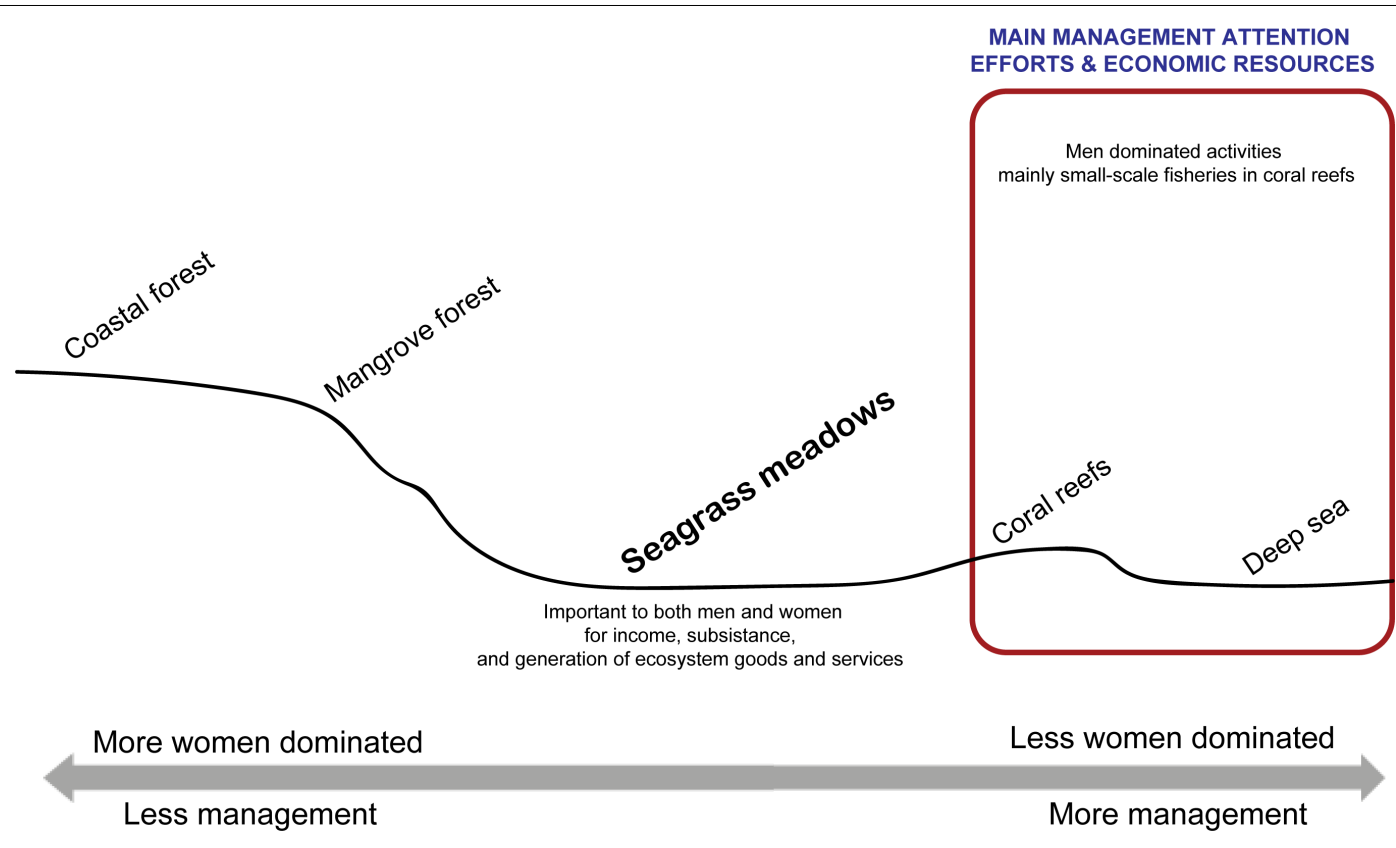

FIGURE 1 | The tropical seascape with differential gender domination and SSF management efforts in Zanzibar, Tanzania. Data from de la Torre-Castro et al. (2017).

of red Euchemoid species is traditionally done over seagrass meadows (de la Torre-Castro and Rönnbäck, 2004) and negative effects have been identified for seagrasses and macrofauna (Eklöf et al., 2005); farms hinder potential seagrass biomass increase, especially in tall and large seagrass species (Eklöf et al., 2006b) and they change seagrass fish community composition (Eklöf et al., 2006a). In addition to the ecological changes, farming had a detrimental effect on farmers' health (Fröcklin et al., 2012) and income provision was too low to be able to break poverty traps (de la Torre-Castro et al., 2017).

Gender inequalities were found in access to ecosystems and management focus (management was always androcentric), but seagrasses were of high value to both men and women and, relative to other ecosystems, provided good income generation (de la Torre-Castro et al., 2017). The study also shows that women have a strong spirit of entrepreneurship. Literature has found that women are normally "motors" of economic development (e.g., Jerneck, 2018). There is a lot to do in this regard and attention has been given to, for instance, the role of women in fish markets (Fröcklin et al., 2013) and for the whole fish value chain (Drury O'Neill and Crona, 2017). Fish associated with seagrasses seem to dominate catches in the Western Indian Ocean, so these points are central to policy (e.g., Wanyonyi, 2018).

In terms of seagrass conservation, both men and women were concerned for their status. However, the need to perform economic activities that in many cases damage the meadows (e.g., aquaculture, fishing with drag-nets) hinders conservation. Here the intersectionality perspective (Crenshaw, 1991; Lykke, 2009 chapter 5); could be of great value. Intersectionality refers to the analysis of how gender and other categories such as class, race, etc. interact, and it has been identified as a key issue for future research in gender and environment (Hawkins et al., 2011;
Nightingale, 2011; Ravera et al., 2016). In tropical seagrasses settings, problems of gender and poverty are deeply intertwined. In temperate settings, other issues like gender and education may play an important role.

For seagrass ecosystems in general, there is an imbalance between knowledge of the ecological system vs. the social one. There is a lot of knowledge about the ecology of seagrass meadows, but relatively little about their fisheries and other types of societal goods and services (Nordlund et al., 2018). The gendered social-ecological analysis proposed here is just at the beginning, thus replication of these type of studies is urgently needed for the improvement of management and for policy reform.

The research described above covered the three first layers of knowledge and partly the fourth layer of the model (see Table 1). However, the next layers require cooperation with local people, managers and civil society organizations. Scientific research alone is not enough to fulfill the whole management cycle, which includes other actors than researchers and other processes than just scientific enquiry. Managers, resource users, organizations, testing and reevaluation are structures and processes of management cycles. There is a need to include scientific work in formal management processes in new and productive ways. Research-financing bodies can play an important role supporting initiatives linking science with real management situations.

\section{CONCLUSION}

As discussed above, dealing with gender and coastal/marine management is a complex task putting high demands on the way SSF should be handled. Gender inclusion in governance, 
management and policy requires a new way of thinking and significant knowledge about how to understand gender both vis-à-vis nature and social relations. There are no simple ways to perform social-ecological analyses that integrate gender. In this text, it is argued that gender inclusion seems to be positive for promoting ocean/coastal sustainability. The text provides the basis for this argument; the why, based on evidence of previous experiences with other systems (e.g., forestry, water, agriculture, etc.) where gender inclusion has been positive and desirable, The inclusion of women has been found to be positive in terms of participation; space, actors and activities; economic power, as well as equity and environmental stewardship. Based on this knowledge, it is concluded that "inclusive management" which integrates gender and the involvement of women might be a way forward to help to address the bad situation of ocean/coastal resources. Inclusive management is considered here as any management option that explicitly and consciously considers a diversity of actors (and the first obvious ones are men and women). Knowing the why is necessary but not sufficient; there is also a need to address the how. This contribution provides an organized way to address gender integration for management enhancement and policy reform. A social- ecological model to understand gender is proposed as a hands-on way to work with inclusive management and to facilitate gender analysis. The model is built by superimposing layers of knowledge in which gender analysis is embedded. The social-ecological nature of the model, by considering both social/cultural factors and the access to and use of ecosystems and ecological resources, makes it a good candidate to facilitate the understanding of gendered situations and to visualize management and policy reform.

\section{A FEW WORDS ABOUT THE FUTURE}

As the "Anthropocene" continues unfolding, instability, shocks and disturbances are expected to increase (e.g., Steffen et al., 2011). New institutions and environmental management regimes are urgently needed to curb degradation and boost optimism. In this regard, resilient systems are needed in order to be able to tackle disturbance. Since resilience is enhanced by diversity (e.g., Folke et al., 2004) adding gender has great potential to facilitate progress toward positive pathways.

However, gender and resilience research is still in its infancy. Two recent studies reach opposite conclusions; one states that it is better to maintain a pluralistic approach and diversity of methods, i.e., not only using resilience thinking (Kawarazuka et al., 2017), whilst the other study advocates for linking resilience

\section{REFERENCES}

Agarwal, B. (2009a). Gender and forest conservation: the impact of women's participation in community forest governance. Ecol. Econ. 68, 2785-2799. doi: 10.1016/j.ecolecon.2009. 04.025

Agarwal, B. (2009b). Rule making in community forestry institutions: the difference women make. Ecol. Econ. 68, 2296-2308. doi: 10.1016/j.ecolecon. 2009.02.017 and critical feminist social theory (Iniesta-Arandia et al., 2016). There is a clear need to develop more gender research in Natural Resource Management and link to key approaches such as resilience, vulnerability, limits of growth and the relatively new approach for Earth sustainability, i.e., the planetary boundaries (Steffen et al., 2015).

For SSF it is imperative to advance gender knowledge. Quantitative as well as qualitative data is needed. Quantitative studies are crucial for economic analysis for example, while qualitative research, for example in the form of rich narratives, are key for in-depth understanding of the gendered socialecological situation. SSF are context specific, but in the contemporary world, they are connected to global markets and peoples' lifestyles. So cross-scale considerations are needed too. Moreover, since a vast majority of SSF take place in the tropics, clear links to the Sustainable development goals (SDGs) are necessary (Agenda 2030, 2015). In this regard, the most obvious links are between goal no. 14 "Life below the water" and goal no. 5 "Gender equality." As gender research in SSF grows stronger, the FAO voluntary guidelines for SSF (FAO, 2015) will gain in legitimacy and knowledge acquisition, bringing a positive development for global SSF's future.

\section{AUTHOR CONTRIBUTIONS}

MdlT-C conceived the idea, wrote the whole manuscript, and analyzed the literature.

\section{FUNDING}

The Swedish Research Council (Vetenskapsrådet) supported this research through the grant number: 344-2011-5448. Publish open access support was provided by Stockholm University.

\section{ACKNOWLEDGMENTS}

This research was possible with grant funds provided by the Swedish Research Council (Vetenskapsrådet). Dr. No. 344-201105448. Prof. Lars Lindström and Dr. Sara Fröcklin provided valuable comments on earlier versions of the manuscript as well as two reviewers. Caitlin McCormack and Astrid Max gave important inputs in language and edition. Thanks to colleagues in Tanzania, authorities and local people, who has supported our research over time. 
Arjunan, M., Holmes, C., Puyravaud, J. P., and Davidar, P. (2006). Do developmental initiatives influence local attitudes toward conservation? A case study from the Kalakad-Mundanthurai Tiger Reserve, India. J. Environ. Manage. 79, 188-197. doi: 10.1016/j.jenvman.2005.06.007

Arora-Jonsson, S. (2014). Forty years of gender research and environmental policy: Where do we stand? Womens Stud. Int. Forum 47, 295-308. doi: 10.1016/j.wsif. 2014.02.009

Barclay, K., McClean, N., Foale, S., Sulu, R., and Lawless, S. (2018). Lagoon livelihoods: gender and shell money in Langalanga, Solomon Islands. Marit. Stud. 17, 199-211. doi: 10.1007/s40152-018-0111-y

Barclay, K., Voyer, M., Mazur, N., Payne, A. M., Mauli, S., Kinch, J., et al. (2017). The importance of qualitative social research for effective fisheries management. Fish. Res. 186, 426-438. doi: 10.1016/j.fishres.2016.08.007

Béné, C., Arthur, R., Norbury, H., Allison, E. H., Beveridge, M., Bush, S., et al. (2016). Contribution of fisheries and aquaculture to food security and poverty reduction: assessing the current evidence. World Dev. 79, 177-196. doi: 10.1016/ j.worlddev.2015.11.007

Bennett, E. (2005). Gender, fisheries and development. Mar. Policy 29, 451-459. doi: 10.1016/j.marpol.2004.07.003

Boserup, E. (1970). Woman's Role in Economic Development. London: George Allen and Unwin.

Braidotti, R., Charkiewicz, E., Häusler, S., and Wieringa, S. (1994). Women, the Environment and Sustainable Development: Towards a Theoretical Synthesis. London: Zed Books.

Broeckhoven, N., and Cliquet, A. (2015). Gender and ecological restoration: time to connect the dots. Restor. Ecol. 23, 729-736. doi: 10.1111/rec.12270

Bryson, V. (2003). Feminist Political Theory: An Introduction. Basingstoke: Palgrave Macmillan. doi: 10.1007/978-0-230-00576-1

Cotter, D. A., DeFiore, J. A., Hermsen, J. M., Kowalewski, B. M., and Vanneman, B. (1997). All women benefit: the macro-level effect of occupational integration on gender earnings equality. Am. Sociol. Rev. 62, 714-734. doi: 10.2307/2657356

Crenshaw, K. (1991). Mapping the margins: intersectionality, identity politics, and violence against women of color. Stanford Law Rev. 43, 1241-1299. doi: $10.2307 / 1229039$

Dankelman, I. (2001). "Gender and environment: lessons to learn," in Encyclopedia of Life Support Systems, ed. UNESCO (Oxford: EOLLS Publishers Co. Ltd.), 28.

Davis, D. L., and Nadel-Klein, J. (1992). Gender, culture, and the sea - contemporary theoretical approaches. Soc. Nat. Resour. 5, 135-147. doi: $10.1080 / 08941929209380782$

de la Torre-Castro, M. (2012). Governance for sustainability: insights from marine resource use in a tropical setting in the western Indian ocean. Coast. Manage. 40, 612-633. doi: 10.1080/08920753.2012.727738

de la Torre-Castro, M., Frocklin, S., Borjesson, S., Okupnik, J., and Jiddawi, N. S. (2017). Gender analysis for better coastal management - Increasing our understanding of social-ecological seascapes. Mar. Policy 83, 62-74. doi: 10.1016/j.marpol.2017.05.015

de la Torre-Castro, M., and Rönnbäck, P. (2004). Links between humans and seagrasses - an example from tropical East Africa. Ocean Coast. Manage. 47, 361-387. doi: 10.1016/j.ocecoaman.2004.07.005

Di Chiro, G. (2008). Living environmentalisms: coalition politics, social reproduction, and environmental justice. Environ. Polit. 17, 276-298. doi: $10.1080 / 09644010801936230$

Diamond, N. K., Squillante, L., and Hale, L. Z. (2003). Cross currents: navigating gender and population linkages for integrated coastal management. Mar. Policy 27, 325-331. doi: 10.1016/S0308-597X(03)00044-7

Drury O'Neill, E., and Crona, B. (2017). Assistance networks in seafood trade A means to assess benefit distribution in small-scale fisheries. Mar. Policy 78, 196-205. doi: 10.1016/j.marpol.2017.01.025

Drury O’Neill, E., Crona, B., Ferrer, A. J. G., Pomeroy, R., and Jiddawi, N. S. (2018). Who benefits from seafood trade? A comparison of social and market structures in small-scale fisheries. Ecol. Soc. 23:12. doi: 10.5751/es-10331230312

Duflo, E. (2012). Women empowerment and economic development. J. Econ. Lit. 50, 1051-1079. doi: 10.1257/jel.50.4.1051

Eklöf, J. S., de la Torre-Castro, M., Adelskold, L., Jiddawi, N. S., and Kautsky, N. (2005). Differences in macrofaunal and seagrass assemblages in seagrass beds with and without seaweed farms. Estuar. Coast. Shelf Sci. 63, 385-396. doi: 10.1016/j.ecss.2004.11.014
Eklöf, J. S., de la Torre-Castro, M., Nilsson, C., and Rönnbäck, P. (2006a). How do seaweed farms influence local fishery catches in a seagrass-dominated setting in Chwaka Bay, Zanzibar? Aquat. Living Resour. 19, 137-147. doi: 10.1051/alr: 2006013

Eklöf, J. S., Henriksson, R., and Kautsky, N. (2006b). Effects of tropical open-water seaweed farming on seagrass ecosystem structure and function. Mar. Ecol. Prog. Ser. 325, 73-84. doi: 10.3354/meps325073

FAO (2012). Report of the FAO Workshop on Future Directions for Gender in Aquaculture and Fisheries Action, Research and Development. FAO Fisheries and Aquaculture Report No. 998. Food and Agricultural Organization of the United Nations, Shanghai.

FAO (2015). Voluntary Guidelines for Securing Sustainable Small-Scale Fisheries in the Context of Food Security and Poverty Eradication. Rome: Food and Agricultural Organization of the United Nations.

FAO (2017). "Towards gender-equitable small-scale fisheries governance and development: a handbook," in Proceedings of the Support of the Implementation of the Voluntary Guidelines for Securing Sustainable Small-Scale Fisheries in the Context of Food Security and Poverty Eradication, by Nilanjana Biswas, (Rome: Food and Agricultural Organization of the United Nations).

Folke, C., Carpenter, S., Walker, B., Scheffer, M., Elmqvist, T., Gunderson, L., et al. (2004). Regime shifts, resilience, and biodiversity in ecosystem management. Annu. Rev. Ecol. Evol. Syst. 35, 557-581. doi: 10.1146/annurev.ecolsys.35. 021103.105711

Fortnam, M., Brown, K., Chaigneau, T., Crona, B., Daw, T., Goncalves, D., et al. (2019). The gendered nature of ecosystem services. Ecol. Econ. 159, 312-325. doi: 10.1016/j.ecolecon.2018.12.018

Fröcklin, S., de la Torre-Castro, M., Hakansson, E., Carlsson, A., Magnusson, M., and Jiddawi, N. S. (2014). Towards improved management of tropical invertebrate fisheries: including time series and gender. PLoS One 9:12. doi: 10.1371/journal.pone.0091161

Fröcklin, S., de la Torre-Castro, M., Lindström, L., and Jiddawi, N. S. (2013). Fish traders as key actors in fisheries: gender and adaptive management. Ambio 42, 951-962. doi: 10.1007/s13280-013-0451-1

Fröcklin, S., de la Torre-Castro, M., Lindström, L., Jiddawi, N. S., and Msuya, F. E. (2012). Seaweed mariculture as a development project in Zanzibar, East Africa: a price too high to pay? Aquaculture 356, 30-39. doi: 10.1016/j.aquaculture. 2012.05.039

Fröcklin, S., Jiddawi, N. S., and de la Torre-Castro, M. (2018). Small-scale innovations in coastal communities: shell-handicraft as a way to empower women and decrease poverty. Ecol. Soc. 23:34. doi: 10.5751/ES-10136230234

Gregson, N., Kothari, U., Cream, J., Dwyer, C., Holloway, S., Maddrell, A., et al. (1997). Gender in feminist geography. Femin. Geograph. 49-85.

Harding's, S. G. (1986). The Science Question in Feminism. Ithaca, NY: Cornell University Press.

Harper, S., Zeller, D., Hausser, M., Pauly, D., and Sumaila, R. (2013). Women and fisheries: contribution to food security and local economies. Mar. Policy 39, S56-S63. doi: 10.1016/j.marpol.2012.10.018

Hawkins, R., Ojeda, D., Asher, K., Baptiste, B., Harris, L., Mollett, S., et al. (2011). Gender and environment: critical tradition and new challenges. Environ. Plan. D-Soc. Space 29, 237-253. doi: 10.1068/d16810

Hunter, L. M., Hatch, A., and Johnson, A. (2004). Cross-national gender variation in environmental behaviors. Soc. Sci. Q. 85, 677-694. doi: 10.1111/j.0038-4941. 2004.00239.x

Iniesta-Arandia, I., Ravera, F., Buechler, S., Diaz-Reviriego, I., Fernandez-Gimenez, M. E., Reed, M. G., et al. (2016). A synthesis of convergent reflections, tensions and silences in linking gender and global environmental change research. Ambio 45, S383-S393. doi: 10.1007/s13280-016-0843-0

IPCC (2018). "Summary for policymakers," in Global Warming of $1.5^{\circ} \mathrm{C} . \mathrm{An}$ IPCC Special Report on the Impacts of Global Warming of $1.5^{\circ} \mathrm{C}$ Above PreIndustrial Levels and Related Global Greenhouse Gas Emission Pathways, in the Context of Strengthening the Global Response to the Threat of Climate Change, Sustainable Development, and Efforts to Eradicate Poverty, eds V. MassonDelmotte, H. O. Pörtner, D. Roberts, J. Skea, P. R. Shukla, and A. Pirani (Geneva: IPCC).

Jackson, C. (1993). Women nature or gender history - a critique of ecofeminist development. J. Peasant Stud. 20, 389-419. doi: 10.1080/030661593084 38515 
Jackson, C. (1994). "Gender analysis and environmentalism," in Social Theory and the Global Environment, eds M. R. Redclift and T. Benton (London: Taylor \& Francis Ltd.), 113-149.

Jerneck, A. (2018). What about gender in climate change? Twelve feminist lessons from development. Sustainability 10:627. doi: 10.3390/su10030627

Kabeer, N. (1994). Reversed Realities: Gender Hierarchies in Development Thought. London: Verso.

Kawarazuka, N., Locke, C., McDougall, C., Kantor, P., and Morgan, M. (2017). Bringing analysis of gender and social-ecological resilience together in smallscale fisheries research: challenges and opportunities. Ambio 46, 201-213. doi: $10.1007 / \mathrm{s} 13280-016-0814-5$

King, Y. (1983). "Toward and ecological feminism and a feminist ecology," in Machina Ex Dea: Feminist Perspectives on Technology, ed. J. Rothschild (New York, NY: Pergamon Press), 118-128.

Kleiber, D., Harris, L. M., and Vincent, A. C. J. (2015). Gender and small-scale fisheries: a case for counting women and beyond. Fish Fish. 16, 547-562. doi: 10.1111/faf.12075

Klugman, J., Hanmer, L., Twigg, S., Hasan, T., McCleary-Sills, J., and Santamaria, J. (2014). Voice and Agency: Empowering Women and Girls for Shared Prosperity. Washington DC: World Bank. doi: 10.1596/978-1-4648-0359-8

Kooiman, J., Bavinck, M., Jentoft, S., and Pullin, R. (2005). Fish for Life. Interactive Governance for Fisheries. Amsterdam: Amsterdam University Press. doi: 10. 5117/9789053566862

Koralagama, D., Gupta, J., and Pouw, N. (2017). Inclusive development from a gender perspective in small scale fisheries. Curr. Opin. Environ. Sustainabil. 24, 1-6. doi: 10.1016/j.cosust.2016.09.002

Lauber, T. B., Anthony, M. L., and Knuth, B. A. (2001). Gender and ethical judgments about suburban deer management. Soc. Nat. Resour. 14, 571-583. doi: $10.1080 / 089419201750341871$

Leach, M. (2007). Earth mother myths and other ecofeminist fables: how a strategic notion rose and fell. Dev. Change 38, 67-85. doi: 10.1111/j.1467-7660.2007. 00403.x

Lykke, N. (2009). Genusforskning: En Guide Till Feministisk Teori, Metodologi och Skrift. Stockholm: Liber.

Matsue, N., Daw, T., and Garrett, L. (2014). Fish traders on the Kenyan coast: livelihoods, bargaining power, and participation in management. Coast. Manage. 42, 531-554. doi: 10.1080/08920753.2014.964819

Medina, M. A. P., and Toledo-Bruno, A. G. (2016). Ecological footprint of university students: Does gender matter? Global J. Environ. Sci. Manage. 2, 339-344. doi: 10.22034/gjesm.2016.02.04.003

Menon, G. (1991). Ecological transitions and the changing context of women's work in tribal India. Purushatra 291-314.

Merchant, C. (1980). The Death of Nature: Women, Ecology, and the Scientific Revolution. San Francisco, CA: Harper \& Row.

Moser, C. O. N. (1989). Gender planning in the third-world - meeting practical and strategic gender needs. World Dev. 17, 1799-1825. doi: 10.1016/0305-750x(89) 90201-5

Nagoli, J., Binauli, L., and Chijere, A. (2019). Inclusive ecosystems? Women's participation in the aquatic ecosystem in Lake Malawi. Environments 6:3.

Nightingale, A. (2006). The nature of gender: work, gender, and environment. Environ. Plan. D-Soc. Space 24, 165-185. doi: 10.1068/d01k

Nightingale, A. J. (2011). Bounding difference: intersectionality and the material production of gender, caste, class and environment in Nepal. Geoforum 42, 153-162. doi: 10.1016/j.geoforum.2010.03.004

Nordlund, L., Erlandsson, J., de la Torre-Castro, M., and Jiddawi, N. (2010). Changes in an East African social-ecological seagrass system: invertebrate harvesting affecting species composition and local livelihood. Aquat. Living Resour. 23, 399-416. doi: 10.1051/alr/2011006

Nordlund, L. M., de la Torre-Castro, M., Erlandsson, J., Conand, C., Muthiga, N., Jiddawi, N., et al. (2014). Intertidal zone management in the western Indian ocean: assessing current status and future possibilities using expert opinions. Ambio 43, 1006-1019. doi: 10.1007/s13280-0130465-8

Nordlund, L. M., Unsworth, R. K. F., Gullström, M., and Cullen-Unsworth, L. C. (2018). Global significance of seagrass fishery activity. Fish Fish. 19, 399-412. doi: $10.1111 /$ faf.12259

Norgaard, K., and York, R. (2005). Gender equality and state environmentalism. Gen. Soc. 19, 506-522. doi: 10.1177/0891243204273612
Nugent, C., and Shandra, J. M. (2009). State environmental protection efforts, women's status, and world polity: a cross-national analysis. Organ. Environ. 22, 208-229. doi: 10.1177/1086026609338166

Nussbaum, M. (1999). The Professor of Parody: The Hip Defeatism of Judith Butler. Available at: https://newrepublic.com/article/150687/professor-parody

Onyango, P., and Jentoft, S. (2011). Climbing the hill: poverty alleviation, gender relationships, and women's social entrepreneurship in Lake Victoria, Tanzania. Marit. Stud. 10, 117-140.

Palafox-Juárez, E. B., and Liceaga, M. (2017). Spatial diversity of a coastal seascape: characterization, analysis and application for conservation. Ocean Coast. Manage. 136, 185-195. doi: 10.1016/j.ocecoaman.2016. 12.002

Picaulima, S., Teniwut, W. A., Kahfi, S., Teniwut, R. M. K., Susanti, I. I. D. A. R., Hungan, M., et al. (2017). "Mapping marine resources utilization based on seascapes area: a study on gender comparison," in Proceedings of the 2nd International Conference on Applied Marine Science and Fisheries Technology, Bristol. doi: 10.1088/1755-1315/89/1/012027

Rathgeber, E. M. (1990). Wid, wad, gad - trends in research and practice. J. Dev. Areas 24, 489-502.

Ravera, F., Iniesta-Arandia, I., Martin-Lopez, B., Pascual, U., and Bose, P. (2016). Gender perspectives in resilience, vulnerability and adaptation to global environmental change. Ambio 45, S235-S247. doi: 10.1007/s13280-016-0842-1

Revollo-Fernandez, D., Aguilar-Ibarra, A., Micheli, F., and Saenz-Arroyo, A. (2016). Exploring the role of gender in common-pool resource extraction: evidence from laboratory and field experiments in fisheries. Appl. Econ. Lett. 23, 912-920. doi: 10.1080/13504851.2015.1119786

Rocheleau, D., Thomas-Slayter, B., and Wangari, E. (1996). Feminist Political Ecology: Global Issues and Local Experiences. London: Routledge.

Steffen, W., Richardson, K., Rockstrom, J., Cornell, S. E., Fetzer, I., Bennett, E. M., et al. (2015). Sustainability. Planetary boundaries: guiding human development on a changing planet. Science 347:1259855. doi: 10.1126/science.1259855

Schultz, L., Folke, C., and Olsson, P. (2007). Enhancing ecosystem management through social-ecological inventories: lessons from Kristianstads Vattenrike, Sweden. Environ. Conserv. 34, 140-152. doi: 10.1017/s0376892907003876

Scott, J. W. (2012). The Uses and Abuses of Gender. Södertörn Lectures 8. Stockholm: Södertörn University.

Shiva, V. (1989). Staying Alive: Women, Ecology, \& Survival in India. New Delhi: Kali for Women.

Singh, R. K., Rallen, O., and Padung, E. (2013). Elderly Adi Women of Arunachal Pradesh: "Living Encyclopedias" and Cultural Refugia in Biodiversity Conservation of the Eastern Himalaya, India. Environ. Manage. 52, 712-735. doi: 10.1007/s00267-013-0113-x

Song, A. M., Chuenpagdee, R., and Jentoft, S. (2013). Values, images, and principles: what they represent and how they may improve fisheries governance. Mar. Policy 40, 167-175. doi: 10.1016/j.marpol.2013.01.018

Sprague, J. (2005). Feminist Methodologies for Critical Researchers: Bridging Differences. Walnut Creek, CA: Alta Mira Press.

Steffen, W., Persson, A., Deutsch, L., Zalasiewicz, J., Williams, M., Richardson, K., et al. (2011). The anthropocene: from global change to planetary stewardship. Ambio 40, 739-761. doi: 10.1007/s13280-011-0185-x

Thompson, C. (2006). Back to nature? Resurrecting ecofeminism after poststructuralist and third-wave feminisms. ISIS 97, 505-512. doi: $10.1086 / 508080$

Thyresson, M., Crona, B., Nyström, M., de la Torre-Castro, M., and Jiddawi, N. S. (2013). Tracing value chains to understand effects of trade on coral reef fish in Zanzibar, Tanzania. Mar. Policy 38, 246-256. doi: 10.1016/j.marpol.2012.05.041

UNEP (2015). Gender Equality and the Environment. Policy and Strategy. Available at: http://hdl.handle.net/20.500.11822/7655

Veuthey, S., and Gerber, J. F. (2012). Accumulation by dispossession in coastal Ecuador: shrimp farming, local resistance and the gender structure of mobilizations. Global Environ. Change Hum. Policy Dimens. 22, 611-622. doi: 10.1016/j.gloenvcha.2011.10.010

Wanyonyi, I. N. (2018). Migrant (dago) Fishers in Coastal East Africa: Understanding Fisher Migration and its Role in Artisanal Fisheries. Ph.D. thesis, Linnaeus University, Växjö.

Weeratunge, N., Snyder, K. A., and Sze, C. P. (2010). Gleaner, fisher, trader, processor: understanding gendered employment in fisheries and aquaculture. Fish Fish. 11, 405-420. doi: 10.1111/j.1467-2979.2010.00368.x 
Westermann, O., Ashby, J., and Pretty, J. (2005). Gender and social capital: the importance of gender differences for the maturity and effectiveness of natural resource management groups. World Dev. 33, 1783-1799. doi: 10.1016/ j.worlddev.2005.04.018

Williams, M. J. (2002). "Women in fisheries: pointers for development," in Global Symposium on Women in Fisheries, eds M. J. Williams, M. C. Nandeesha, V. P. Corral, E. Tech and P. S. Choo (Kaohsiung: ICLARM - The World Fish Center).

Williams, M. J. (2008). Why look at fisheries through a gender lens? Development 51, 180-185.

World Bank [WB] (2006). Gender Equality as Smart Economics: A World Bank Group Gender Action Plan - Fiscal Years 2007-10. Washington D.C: World Bank.

World Bank [WB] (2010). "Gender and environment," in Proceedings of the 2010 Environment Strategy: Analytical Background Papers, (Washington, DC: World Bank).
World Bank [WB] (2012). World Development Report 2012: Gender Equality and Development. Washington, DC: World Bank.

World Bank [WB] (2015). World Bank Group gender Strategy (FY16-23): Gender Equality, Poverty Reduction and Inclusive Growth. Washington, DC: World Bank Group.

Conflict of Interest Statement: The author declares that the research was conducted in the absence of any commercial or financial relationships that could be construed as a potential conflict of interest.

Copyright (c) 2019 de la Torre-Castro. This is an open-access article distributed under the terms of the Creative Commons Attribution License (CC BY). The use, distribution or reproduction in other forums is permitted, provided the original author(s) and the copyright owner(s) are credited and that the original publication in this journal is cited, in accordance with accepted academic practice. No use, distribution or reproduction is permitted which does not comply with these terms. 